\title{
Uncorrected land-use planning highlighted by flooding: the Alba case study (Piedmont, Italy)
}

\author{
F. Luino, L. Turconi, C. Petrea, and G. Nigrelli \\ Consiglio Nazionale delle Ricerche, Istituto di Ricerca per la Protezione Idrogeologica, Strada delle Cacce 73, \\ 10135 Torino, Italy
}

Correspondence to: F. Luino (fabio.luino@irpi.cnr.it)

Received: 19 March 2012 - Revised: 22 May 2012 - Accepted: 8 June 2012 - Published: 24 July 2012

\begin{abstract}
Alba is a town of over 30000 inhabitants located along the Tanaro River (Piedmont, northwestern Italy) and is famous for its wine and white truffles. Many important industries and companies are based in Alba, including the famous confectionery group Ferrero.

The town suffered considerably from a flood that occurred on 5-6 November 1994. Forty-eight percent of the urban area was inundated, causing severe damage and killing nine people. After the flood, the Alba area was analysed in detail to determine the reasons for its vulnerability.

Information on serious floods in this area since 1800 was gathered from official records, state technical office reports, unpublished documents in the municipal archives, and articles published in local and national newspapers. Maps, plans and aerial photographs (since 1954) were examined to reconstruct Alba's urban development over the last two centuries and the planform changes of the Tanaro River.

The results were compared with the effects of the November 1994 flood, which was mapped from aerial photographs taken immediately after the flood, field surveys and eyewitness reports.
\end{abstract}

The territory of Alba was subdivided into six categories: residential; public service; industrial, commercial and hotels; sports areas, utilities and standards (public gardens, parks, athletics grounds, private and public sport clubs); aggregate plants and dumps; and agriculture and riverine strip. The six categories were then grouped into three classes with different flooding-vulnerability levels according to various parameters. Using GIS, the three river corridors along the Tanaro identified by the Autorità di Bacino del Fiume Po were overlaid on the three classes to produce a final map of the risk areas.
This study shows that the historic floods and their dynamics have not been duly considered in the land-use planning of Alba. The zones that were most heavily damaged in the 1994 flood were those that were frequently affected in the past and sites of more recent urbanisation. Despite recurrent severe flooding of the Tanaro River and its tributaries, areas along the riverbed and its paleochannels have been increasingly used for infrastructure and building (e.g., roads, a municipal dump, a prison, natural aggregate plants, a nomad camp), which has often interfered with the natural spread of the floodwaters. Since the 1994 flood, many remedial projects have been completed along the Tanaro and its tributaries, including levees, bank protection, concrete walls and floodway channels. In spite of these costly projects, some areas remain at high risk for flooding.

The method used, which considered historical data, river corridors identified by hydraulic calculations, geomorphological aspects and land-use planning, can indicate with good accuracy flood-prone areas and in consequence to be an useful tool for the coherent planning of urban expansion and the mitigation of flood risk.

\section{Introduction}

Flood plains have consistently been attractive locations for urban development because of level ground, fertile soil, good sun exposure, ease of access and plentiful water. Human use has been constant and extensive, and growing urban pressures are causing additional development. The flood risk has not been adequately considered, and the use of flood plains has often resulted in loss from floods or in the expense of adequate protection (Waananen et al., 1977). The increase in 
flood damage in the last decades has generally been caused by the human settlement of flood plains, which increases exposed property and population within flood-prone areas.

The detection of areas that are potentially subject to flooding has been one of the most frequent debates among the scientific community in Italy during the last decades (Caroni et al., 1990; Govi and Turitto, 1994; Dutto, 1994; Giacomelli et al., 1998; Maraga and Turitto, 1998; Oliveri et al., 1998; Sole and D'Angelo, 1999; De Martino et al., 2000; Luino et al., 2002a; Aronica et al., 2002; Aureli et al., 2006; Castellarin et al., 2011) and internationally (Oya, 1971; Wolman, 1971; Newson, 1975; Waananen et al., 1977; Dunne and Leopold, 1978; Tag-Eldeen and Nilsson, 1979; Mayer and Nash, 1987; Leroi, 1996; Faisal et al., 1999; Tucci and Villanueva, 1999; Bates and De Roo, 2000; Sharma and Priya, 2001; Berg, 2002; Horritt and Bates, 2002; Sinnakaudan et al., 2003; Hardmeyer and Spencer, 2007; Pappenberg et al., 2007; Gilles et al., 2012).

The identification of areas prone to severe floods can be approached by different methods. Some authors have used specific criteria, including historical (Luino, 2002; Tropeano and Turconi, 2004; Coeur and Lang, 2008), geomorphological (Maraga, 1986; Baker et al., 1987; FernandezLavado et al., 2007; Benito and Hudson, 2010), hydrologichydraulic (Dawson and Wilby, 1999; Brych et al., 2002; Diez-Herrero et al., 2009; Musall et al., 2011), and remotesensing methods (Jain et al., 2005; Hui et al., 2008). Other authors have combined methods, which can yield better results because the technique can compensate for the limitations of individual methods. Notable results have been achieved, for example, by combining historical and geomorphological methods (Luino et al., 2002b) or geomorphological and hydrological methods (Chen and Simons, 1986; Townsend and Walsh, 1998; Lastra et al., 2008; Lelièvre et al., 2008; Chouari, 2009; Ballard et al., 2011) or by an approach based on historical-hydrogeomorphological reconstitution and hydrological-hydraulic modelling (Santos et al., 2011).

In the last decades, GIS (Geographical Information Systems) and LiDAR (Laser Imaging Detection and Ranging) have been important tools in spatial processing. GIS uses a series of software tools to capture, store, extract, transform and display real-world spatial data (Burrough, 1986), whereas LiDAR is an optical remote-sensing technology for creating high-resolution digital models of the earth's surface. LiDAR is particularly useful because the ongoing construction of levees, dikes, roads, railway embankments and buildings constantly changes the land's appearance.

Regardless of the method, the quality of the results obtained is always dependent on the assessment of the natural world. Only after a flood can a model be re-calibrated and inadequacies improved.

The demarcation of flood-prone areas has been requested by local citizens, industries and organisations, as well as state and regional bodies responsible for disaster prevention
(Smith, 1994; Du Plessis and Viljoen, 1999; Loáiciga, 2001; Messner and Meyer, 2006; Brody et al., 2008; Jonkman et al., 2008; Luino et al., 2012). In the last $25 \mathrm{yr}$, insurance companies have shown interest in this field and various papers and reports have been published (Arnell, 1987; Smith, 1994; FEMA, 1997; Munich Re, 1997; Glaschen et al., 1998; Blanchard-Boehm et al., 2001; Kron, 2009; Bhattamishra, 2010). It is important to be able to estimate the likelihood and the social, economic and environmental consequences of a disaster (Van der Sande, 2001; Queensland Government, 2002; Liu and Liu, 2002; FEMA, 2003; United Nations, 2006).

In Italy, the increasing vulnerability of land along watercourses is mainly due to intensive urbanisation, which has accelerated since the 1960s. Urban development has not been controlled by careful land management that considers natural threats. Useful information about historic floods (e.g., flooded areas, flow velocity, erosion processes, damage) has rarely been taken into account. For this reason, local bodies (e.g., interregional authorities, regional and provincial administrations, and municipalities) must now address socioeconomic difficulties.

In 1989, the Italian government passed an environmental protection law (Law 183/89) that created several "Autorità di Bacino" (Basin Authorities). They are mixed state and regional organisations responsible for hydrographic basins. The Basin Authorities consider the hydrographic basins unitary systems for the purposes of land and subsoil conservation, water reclamation, water-resource management and environmental protection, regardless of administrative divisions. This legislative innovation in the conservation sector is a result of the famous "Commissione De Marchi" that created the conditions for broad, integrated solutions to landmanagement problems on the basin scale after the severe flood that hit Florence in November 1966.

The objective of the Basin Authorities was to overcome the institutional divisions that prevent unified and integrated planning for the major European basins. The Authorities coordinate planning among the institutions involved in the conservation, use and control of resources in accordance with social, economic and environmental sustainable development.

The Basin Authorities introduced, for example, the concept of a "river corridor", which is defined as "the area of land (and water) affecting and/or affected by a river" (Gardiner, 1991), an important concept for geomorphologists that had not previously been defined by clear regulation.

For each watercourse of a main hydrographic network, river corridors are identified as follows: (1) the limits of the riverbed and flood-prone areas with respect to large floods; (2) the conditions of the defense system, including levees, bank protection, flood-control works, and floodways; (3) riverbed morphology and geometry; and (4) type of land use in the valley bottom.

The Po River Basin Authority, which is responsible for the Tanaro River, classifies the river corridors as follows: 
channel A, for ordinary floods; channel B, for 200-yr return period floods; and channel C, for catastrophic 500-yr return period floods (Autorità di Bacino del Fiume Po, 1997). The method of defining these river corridors uses three criteria, hydrodynamic, geomorphological and ecological, to identify three strips of different amplitudes. The goal of the "River Corridor Plan" is to plan resource use within the fluvial region to preserve the correct operation of fluvial processes (hydraulic, geomorphological and ecological) in accordance with human requirements and existing use (Baruffi et al., 2005). The regulation of activities within the corridors has prevented uncontrolled urban development along the river and other human action that has threatened the natural balance of watercourses in the recent past (Passino, 1996).

Following the severe floods of 1992, 1993 and 1994, the Piedmont Regional Administration, in collaboration with regional professional associations, adopted regulatory guidelines and standards that must be observed during the drafting of geological studies in support of planning instruments. Circular 7/LAP/1996 and Technical Note/1999 identify the guidelines as a regional standard for the implementation of the "check of hydraulic and hydrological compatibility with the future planning instruments with the conditions of instability...".

Despite these efforts, recent field surveys have found new residential and commercial construction along watercourses, particularly in mountain areas where municipal administrations manage the streams within their municipalities as they see fit. In this unregulated land management, the complaisance of engineers and geologists has proved decisive. These freelancers are paid by the municipalities and have largely worked to satisfy municipality demands, constantly attempting to bypass land restrictions through legislative chicanery that seeks amnesty for the infringement of local building regulations and variations of the land-use plan instead of observing the existing laws.

Finally, in 2007, the European Community adopted Directive 2007/60/EC. "The aim of this Directive is to establish a framework for the assessment and management of flood risks, aiming at the reduction of the adverse consequences for human health, the environment, cultural heritage and economic activity associated with floods in the Community" (Directive 2007/60/EC). With this directive, an improvement in land management and a decrease in errors in land-use planning can be anticipated.

\section{The 5-6 November 1994 event and the Alba flood}

\subsection{Meteorological conditions}

The flood of 5-6 November 1994 was one of the most disastrous in the Tanaro river basin in the last two centuries. During this period, only one comparable flood occurred, in May 1879. During the first week of November 1994, a

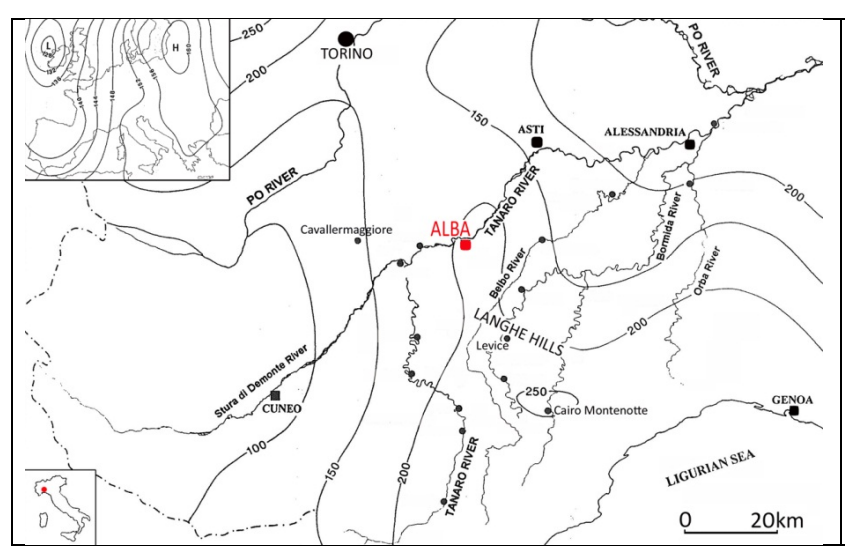

Fig. 1. Map of the Tanaro basin with the isohyetal $(\mathrm{mm})$ pattern for 2-6 November 1994. In the upper-left corner is a meteorological map of the conditions prevailing just before the catastrophic event (4 November 1994, 24:00 LT, 850 hPa) (from the European Meteorological Bulletin of the Deutscher Wetterdienst, modified).

persistent wide depression over northwestern Europe produced heavy rains over a large portion of Piedmont (Fig. 1). The highest intensities, $35-40 \mathrm{~mm} \mathrm{~h}^{-1}$ with a peak of $55 \mathrm{~mm} \mathrm{~h}^{-1}$ (Cairo Montenotte raingauge), occurred during the night of 4 November. Precipitation extended north to the region of Asti and the Langhe hills, where rain gauges recorded an intensity of over $200 \mathrm{~mm} \mathrm{day}^{-1}$, with a peak of $264.6 \mathrm{~mm} \mathrm{day}^{-1}$ at the Levice station. On 6 November the rainfall intensity dropped over the Tanaro basin in the early hours of the morning, while the most intensive rainfall hit northwest Piedmont following a SE-NW direction. In an area with an average annual rainfall of approximately 850 $1100 \mathrm{~mm}$, rainfall of approximately $200-230 \mathrm{~mm} \mathrm{day}^{-1}$ was recorded by numerous rain gauges.

Unusual river discharges peaked at $7.3 \mathrm{~m}^{3} \mathrm{~s}^{-1} \mathrm{~km}^{-2}$ (Luino, 1999). Extensive river flooding caused serious losses in 38 urbanised areas: the percentages of flooded urban surfaces were between $10 \%$ and $90 \%$ and averaged $30 \%-50 \%$, with water elevations reaching approximately $1 \mathrm{~m}$ and maximum values of $2.5-3 \mathrm{~m}$. The Tanaro also flooded Alba, Asti and Alessandria, important towns with more than 30000 inhabitants (Luino et al., 1996). Locally, buildings increased their hydraulic levels, creating momentary barriers (e.g., walls, doors, fences). The forces created by the floodwaters caused many buildings to suddenly collapse, which witnesses heard as booms and crashes. The collapsing buildings caused small surges that increased the floodwater's level at a rate of approximately $10 \mathrm{~cm} \mathrm{~min}^{-1}$.

The effect of this event was catastrophic: it left 44 dead and 2000 homeless and killed thousands of animals. Kilometres of roads and railways were washed out, stranding hospitals and schools. Electrical power was cut, and hundreds of factories were crippled. The total damage to publicly 


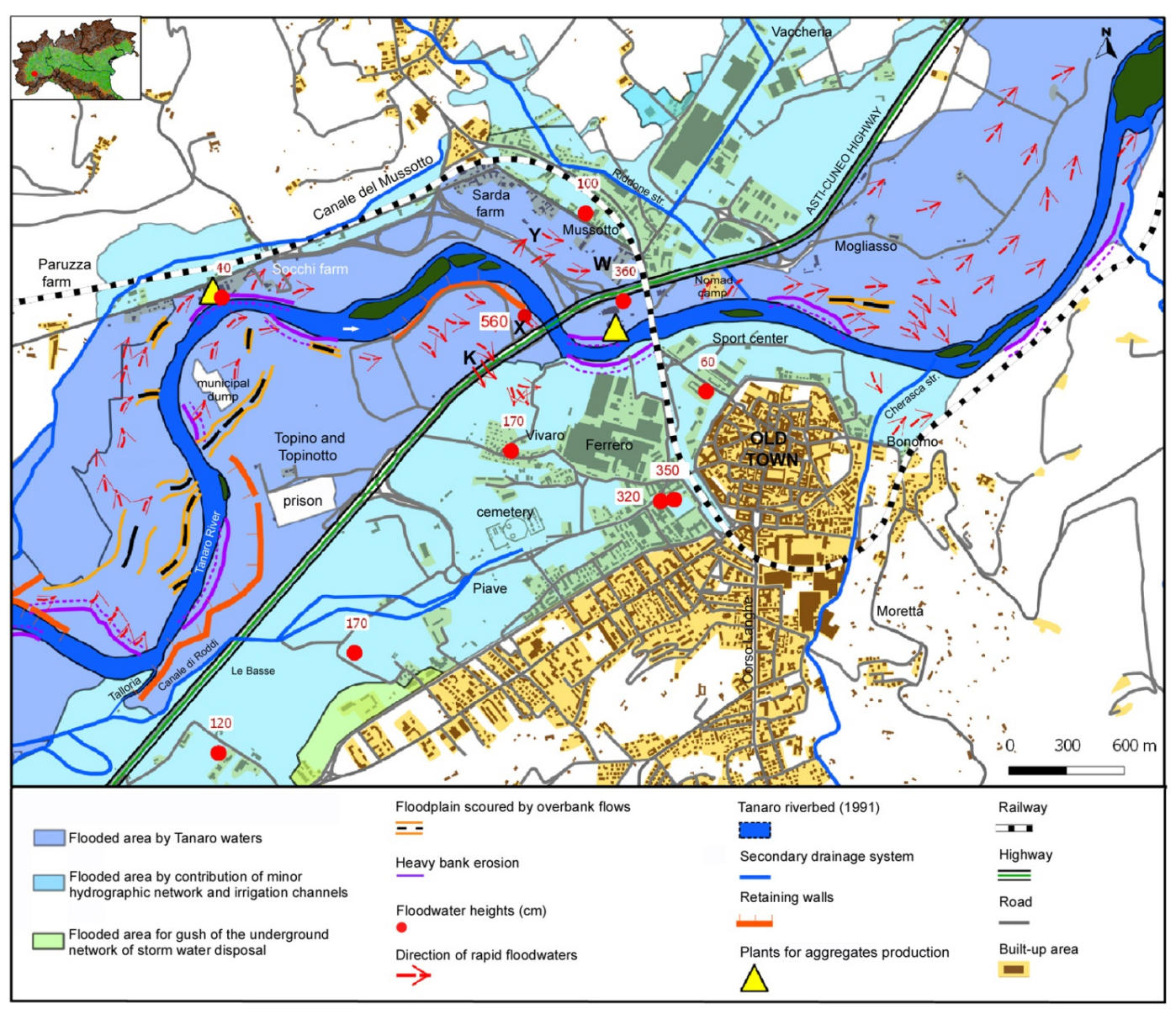

Fig. 2. 5-6 November 1994 flooding in the Alba area.

owned property alone was estimated at US\$ 14 billion, equal to $1.2 \%$ of the gross Italian national product in 1994 .

\subsection{The Alba flood}

On 5 November 1994, beginning in midday, the first floods occurred along the Riddone stream and Canale del Mussotto, severely flooding the Socchi and Mussotto quarters. At the same time, the Cherasca stream inundated part of the Bonomo quarter. The Talloria's floodwaters overflowed on the right bank near the stream's mouth, ran toward the town and, together with the Canale di Roddi waters, flooded several buildings in Le Basse quarter before striking the Piave and Vivaro quarters. During a second phase, the Talloria floodwaters reached the famous Ferrero plant at 17:3018:00 LT, filling the plant's yards and buildings to a height of $60-70 \mathrm{~cm}$. In the Piave quarter at the foot of the hill, basement flats and ground floors were flooded $(20-40 \mathrm{~cm})$ by the runoff coming from the saturated slopes or by the malfunctioning of the sewage system.

In the following hours, the Tanaro inundation reached its paroxysmal phase (Fig. 2). The severe overflow and the violent passage of the waters over the ground left deep scour erosions on the left bank at the river's confluence with the Talloria stream, near the sand-and-gravel separating plant, and on the right bank. The floodwaters spread into the Socchi area between 23:00 and 24:00 LT. Similar severe processes affected the right bank, where the old levee broke and the waters cut deep scour erosions as they flowed around the large blockage created by the municipal dump.

The floodwaters spreading out on the Topino plain were dammed by the embankment of the Asti-Cuneo highway, where they reached $5.6 \mathrm{~m}$ in height (Fig. 3). After the embankment gave way to the waters along the lower stretch, the flood struck Alba. At 22:30 LT, violent waves burst into the Ferrero company plant, demolishing its external wall and inundating all of the buildings to a height of $2.80-3 \mathrm{~m}$. Between 24:00 and 01:00 LT on 6 November, the water in the lower zones of the Vivaro quarter was approximately $3.25 \mathrm{~m}$ deep.

Meanwhile, on the left bank, the Tanaro waters overflowed the railway embankment to join the Riddone waters, reaching the Mussotto quarter (Fig. 4). Part of the Tanaro flow sought to return to the riverbed but was dammed by the highway embankment, raising the water level to $3.6 \mathrm{~m}$. The stretch of 


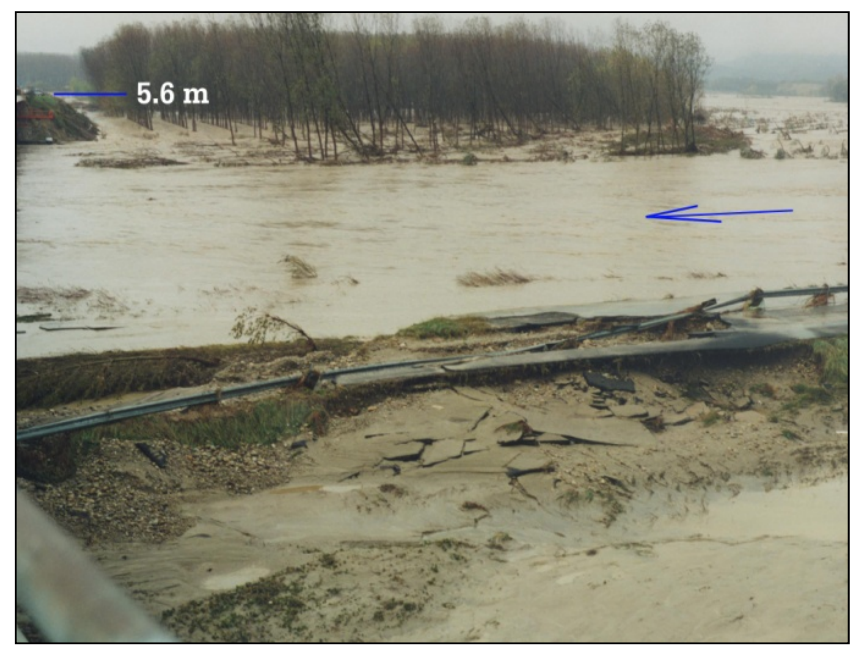

Fig. 3. 6 November 1994, 13:00 LT. The Tanaro River is still swollen. The effects of the flooding are evident. In the foreground, the link road of the Asti-Cuneo highway has been stripped by the violence of the waters. On the left, along the highway embankment, is the site where the deepest floodwaters $(5.60 \mathrm{~m})$ were measured (X in Fig. 2). In the background is a thick poplar forest recently planted in a natural area along the Tanaro.

the Tanaro valley bottom between the confluence of the Talloria and Cherasca streams was flooded by a single expanse of water $2.5 \mathrm{~km}$ in width, on average.

\section{The history of Alba: urban development and land transformation}

Historical studies have shown that a prehistoric settlement of Alba was probably located on the right bank of the Tanaro River, where the waters could flow freely on the valley bottom unhindered by man-made structures. Evidence of a large flood was discovered in a stratum of alluvial deposits, intercalated with strata containing archeological findings. The inhabitants moved their settlement to higher ground slightly to the south along the left bank of the Cherasca stream, where the first Roman camp ("castrum") subsequently arose. The city of Alba became a well-known settlement of the Roman Empire, called Alba Pompeia.

The chief characteristic of the city's historic core is the pseudo-octagon, which was originally bounded by walls built for defensive purposes. In the Middle Ages, Alba became a thriving commune, and the town walls were later reinforced and protected by a deep moat. The town's appearance changed little until the first part of the 19th century, when demolition of the walls began (Cavallari Murat, 1975).

In 1829, the first efforts in modern town planning began, with three goals: to pave the streets; to mitigate the traffic of carts, carriages and people; and to improve the general appearance of the town. Modernisation and development

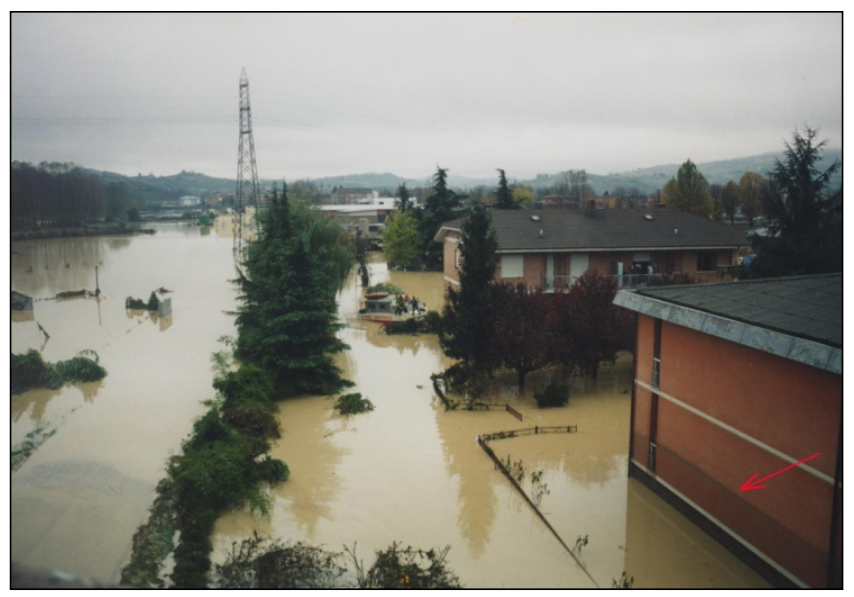

Fig. 4. The Mussotto quarter, close to the highway (W in Fig. 2). The neighbouring Asti-Cuneo embankment, acting as a dam, retained the Tanaro floodwaters, which reached the second floor of the houses (red arrow). In the centre, a fire department rescue boat is in action.

produced works that devastated the existing city fabric. In 1848, a long road bridge across the Tanaro River was built, and this bridge was widened in 1865 to accommodate the new Alessandria-Cavallermaggiore railway line. However, Alba's large-scale expansion did not begin until just after the Second World War. The growth of important companies (Ferrero in confectionery, Miroglio in textiles and Mondo Rubber in sport flooring) attracted more people to the area, leading to a need for housing and infrastructure.

A comparison between the different editions of the official cartography (IGM = Military Geographic Institute) at the 1:25000 scale with the most recent Regional Technical Map at the 1:10 000 scale allows a detailed analysis of Alba's planimetric development since 1852 (Fig. 5). The comparison shows that the urban expansion was modest and uneven until the 1930s and primarily affected the sector east of the historic core (the left bank of the Cherasca stream).

The development that has characterised the post-war period, particularly the recent decades, and relates to the process of industrialisation in the area has occurred mainly along the Corso Piave (toward the SW) and Corso Langhe (toward the S). The highest concentration of new housing and industrial districts has occurred near the Tanaro, both on the left (Mussotto quarter) and right banks (Vivaro quarter), although these quarters have often been hit by floods in the past. Recent important structures and infrastructures built in the Tanaro valley bottom are the aggregate plants, the municipal dump, the Asti-Cuneo highway, the prison and the nomad camp.

The analysis of the planform changes of the Tanaro River, derived from the same cartographic comparison mentioned above, shows a simplification of the riverbed (Fig. 6). In the past, the riverbed was characterised by several channels that 


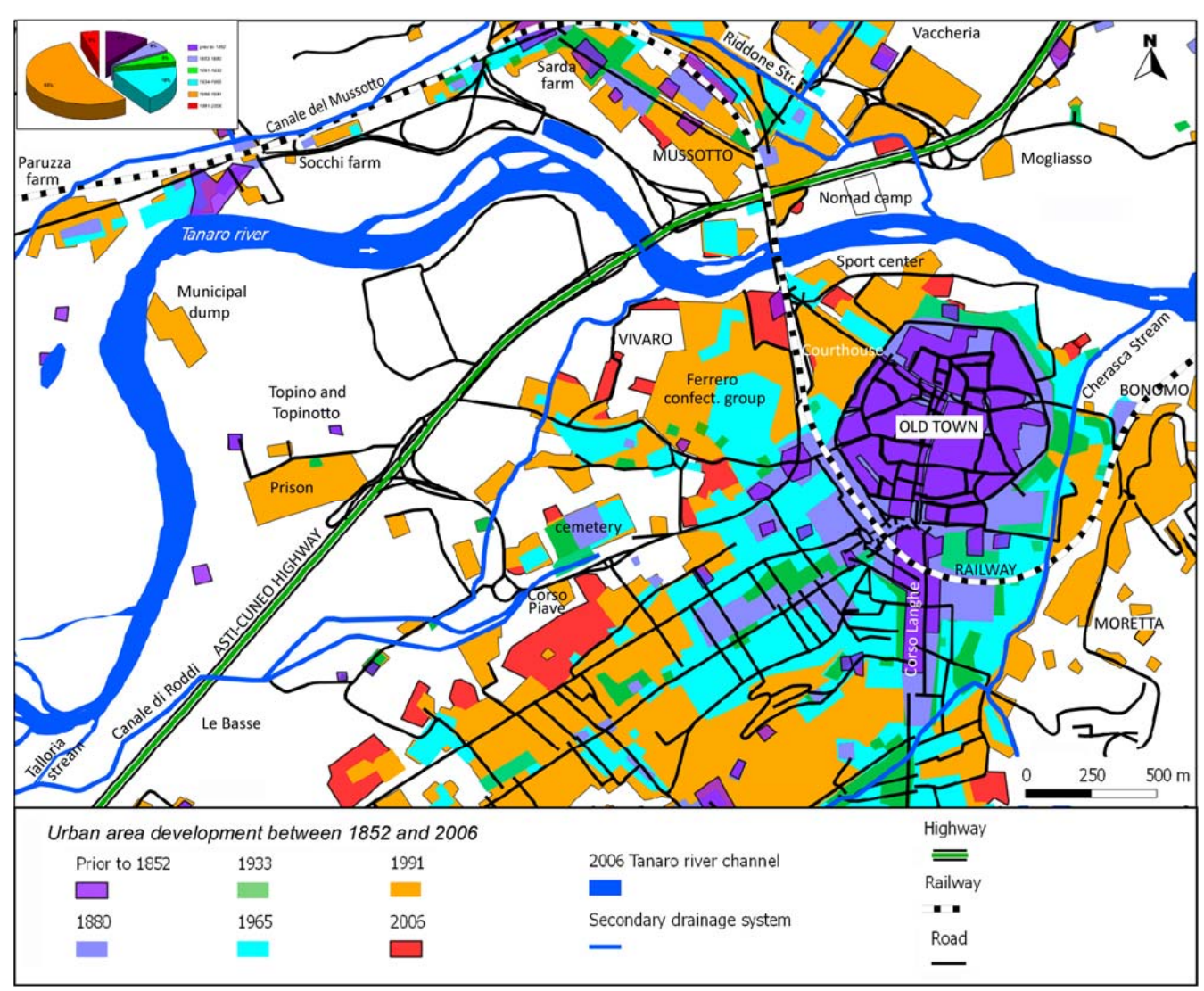

Fig. 5. Urban development of Alba, reconstructed from historical maps with all place names cited in the paper.

were often separated by large vegetated islands. On the 1991 map, the riverbed appears reduced to a single narrow channel without islands.

Documentation relating to the hydraulic defense works along the river was examined (Destefanis, 1928; Ministry of Public Works, Royal Corps of Engineers of Cuneo, unpublished). The documentation reveals that the river's simplification was induced by the numerous and repeated remedial works along the banks since the end of the 19th century. These interventions were performed to create new farmland and, in recent decades, to permit aggregate extraction along the Tanaro's active riverbed.

The defense works, mainly groins and gabions, were principally designed to restrain the mainstream current and minimize the serious threat of riverbank erosion, which is particularly stressful in the bends close to the Socchi and Sarda farms on the left and the Topino and Topinotto farms on the right. In addition, repeated repairs were made on the levees at the Topino bend on the right and, between 1848 and 1850, further downstream on both banks of the river to convey the Tanaro flow under Alba's main bridge.

\section{Historical analysis as a tool for evaluating vulnerable areas}

In recent decades, historical research has become increasingly important. Determining what occurred in a specific area in the past is essential for the prediction of risk scenarios, particularly on a valley floor. Given its location on the flood-prone Tanaro with three hazardous tributaries and many channels, Alba has a long, well-documented history of floods.

For this reason, after the 1994 flood, a thorough analysis of the Tanaro's floods over the last two centuries was performed. The research began with the reading of the long series of observations made at the Pollenzo water-gauge station $\left(3277 \mathrm{~km}^{2}\right.$ basin), located $12 \mathrm{~km}$ upstream of Pollenzo and in operation since 1882 (Perrone, 1916). The data, recorded since 1890 with an interruption from 1950 to 1959 (Ufficio Idrografico e Mareografico per il Bacino del Po, Sezione di Torino), facilitated the identification of floods with water levels higher than $2.50 \mathrm{~m}$ (the height of an ordinary flood) for subsequent investigations.

In addition, publications and technical reports written mainly by the Regional Offices of the State and collected in the CNR-IRPI's archives in Turin were consulted. Similar documents collected in Alba's public library and municipal 


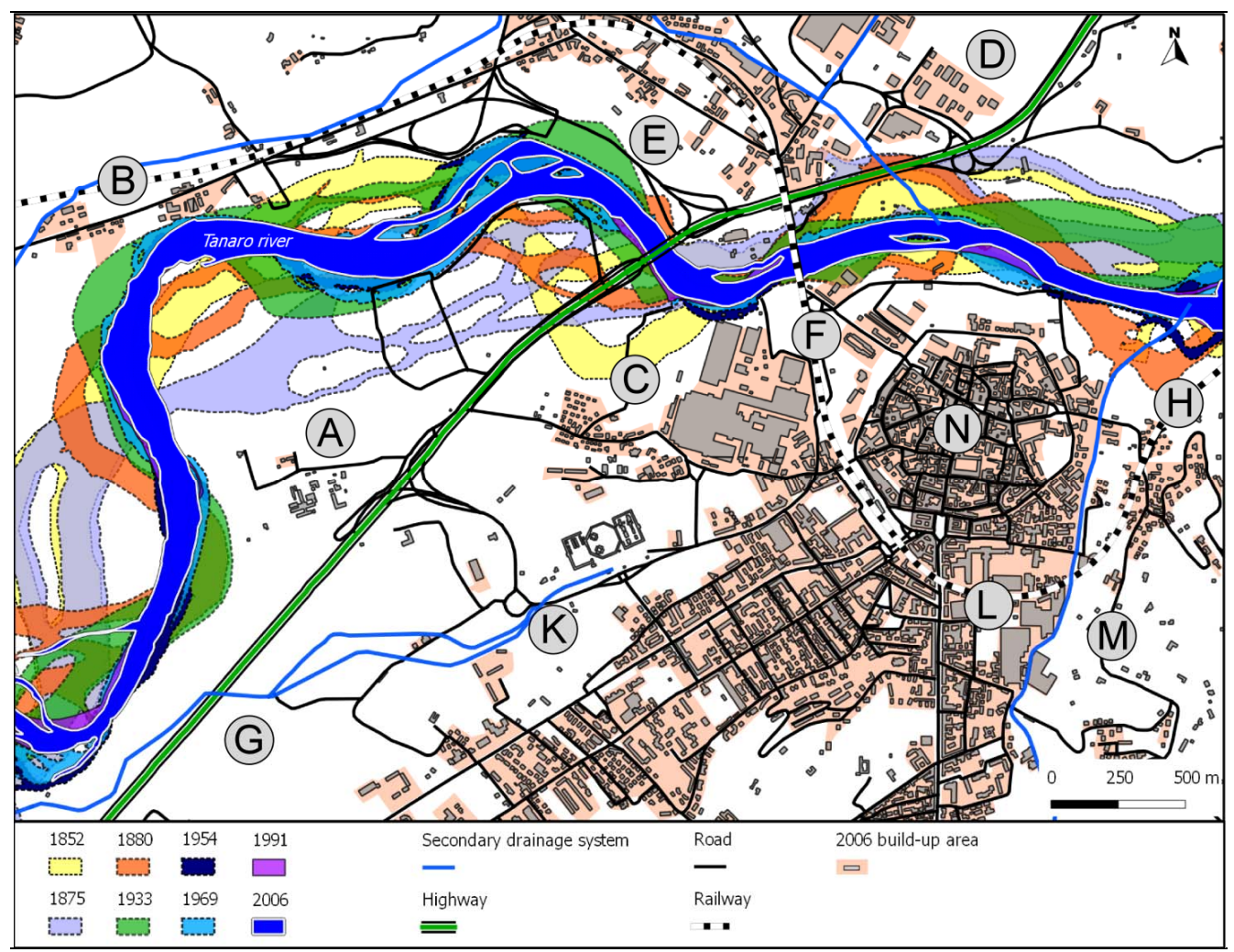

Fig. 6. Planform changes of the Tanaro riverbed during the period 1852-2006 from historical maps. Letters in gray circles indicate Alba's different quarters.

archive as well as articles from national and local newspapers, particularly the local "La Gazzetta d'Alba" founded in 1882, were also examined.

This investigation located information about the effects and damage caused by the floods measured by the Pollenzo water gauge and floods that occurred prior to the Pollenzo observations and during their interruption.

All of the floods selected for study are shown in Fig. 7. In addition to the floods that reached a high hydrometric height $(m>3.60)$, floods without hydrometric references or with low values were considered according to damage documentation.

In Table 1, these floods are listed chronologically with a summary of the information collected on each flood, including watercourse name, effects and damage, and the affected quarter (see Fig. 6).

Some general conclusions can be drawn based on an analysis of the pattern obtained.

- For the floods that occurred before the Pollenzo water gauge station was in use, an assessment of gravity can be made only based on the descriptive information available and without the ability to verify the levels reached by the watercourse. In the case of the May 1879 flood, which equaled and surpassed the previous highest levels at the Asti and Alessandria water gauges, respectively (Luino et al., 1996), we can say that in the Alba area, the flood was exceptional. The large and detailed quantity of data collected has facilitated the confident identification of the affected sectors. In addition, the data have enabled a comparison of the extent and destructiveness of this flood with the flood of November 1994. Information about floods that occurred before 1879 , although significant, is scarce and less detailed. Only rarely can references be found to specific areas of land. However, in some cases, the type of information available has permitted the determination of the "width" of river flooding, even in the absence of detailed information. For the October 1846 flood, for example, the severity of the effects on the Tanaro Valley emerged in several documents. The flooding in the Alba area is described as follows: “... exceptional flood never seen for the Tanaro River occurred in the month of October just expired, and particularly in those most grievously occurred in the period $1-5$ and then in the period 16$20 \ldots$ The fury of the waters invaded, broke, dragged everything from the Alba town till almost to the edge of the opposite hill, so that the Valley of the Tanaro resembled to a narrow sea, dominated by a current" (Prandi, unpublished). 
Table 1. Main effects and damage caused by floods of the Tanaro and its tributaries in different areas of Alba during the period 1801-2000.

\begin{tabular}{|c|c|c|c|}
\hline Date of the flood & $\begin{array}{l}\text { Damaged areas } \\
\text { (see Fig. 6) }\end{array}$ & Watercourse & Effects - Damage \\
\hline May 1817 & $\mathrm{~A}-\mathrm{C}$ & TANARO & Overflows, Floods - Road network \\
\hline 26 Oct 1829 & $A-C$ & TANARO & $\begin{array}{l}\text { Overflows - Buildings, bridges, road network on the } \\
\text { right }\end{array}$ \\
\hline 2 Oct 1846 & $\mathrm{~B}$ & TANARO & $\begin{array}{l}\text { Large Inundations - Bank protection, pontoon bridge, } \\
\text { road network }\end{array}$ \\
\hline 20 Oct 1851 & B & $\begin{array}{l}\text { TANARO } \\
\text { Cherasca }\end{array}$ & $\begin{array}{l}\text { Overflows, Bank Erosion - Road network, municipal } \\
\text { bridges }\end{array}$ \\
\hline 21 Oct 1857 & $\mathrm{~F}$ & TANARO & Bank protection \\
\hline 18 Oct 1872 & $\mathrm{~A}-\mathrm{C}$ & TANARO & $\begin{array}{l}\text { Overflows, Floods, Bank erosion - Channels, buildings, } \\
\text { factories }\end{array}$ \\
\hline 4 Dec 1872 & $\mathrm{~A}-\mathrm{C}$ & TANARO & Overflows, Bank erosion - Bank protection \\
\hline 28 May 1879 & $\begin{array}{l}A-B-C-D \\
F-H\end{array}$ & $\begin{array}{l}\text { TANARO, Talloria, } \\
\text { Cherasca }\end{array}$ & $\begin{array}{l}\text { Large inundations, Floods, Bank erosion - Bank } \\
\text { protection, buildings, road network, railway, } \\
\text { municipal waterworks }\end{array}$ \\
\hline 23 May 1893 & $A-B-D-E-F$ & TANARO & $\begin{array}{l}\text { Overflows, Floods, Bank Erosion - Buildings, } \\
\text { road network }\end{array}$ \\
\hline 4 Jun 1900 & $A-B-E-G$ & TANARO & $\begin{array}{l}\text { Large inundations, Floods, Bank erosion - Railway and } \\
\text { road bridge, road network, bank protection, power } \\
\text { stations }\end{array}$ \\
\hline 16 May 1926 & $A-G$ & $\begin{array}{l}\text { TANARO } \\
\text { Talloria } \\
\text { Cherasca }\end{array}$ & $\begin{array}{l}\text { Large inundations, Floods, Bank erosion - Buildings, } \\
\text { road network }\end{array}$ \\
\hline 10 May 1936 & $\mathrm{D}-\mathrm{G}$ & TANARO & $\begin{array}{l}\text { Overflows, Floods, Bank erosion - Bank protection, } \\
\text { buildings, road network }\end{array}$ \\
\hline 7 Apr 1941 & $\mathrm{~A}-\mathrm{F}$ & TANARO & Overflows, Bank erosion - Bank protection \\
\hline 28 Oct 1942 & $\mathrm{~B}$ & TANARO & Overflows, Erosion left bank - Bank protection \\
\hline 15 May 1948 & $A-B-D-E-F$ & TANARO & $\begin{array}{l}\text { Overflows, Floods, Bank erosion - Bank protection, } \\
\text { buildings }\end{array}$ \\
\hline 4 and 12 Sep 1948 & $\begin{array}{l}A-B-C-D-E-F- \\
H-K \\
L-M\end{array}$ & $\begin{array}{l}\text { TANARO } \\
\text { Cherasca, } \\
\text { Misureto, } \\
\text { Talloria }\end{array}$ & $\begin{array}{l}\text { Estese inondazioni, Floods, Bank Erosion - Bank } \\
\text { protection, building, road network, bridges, municipal } \\
\text { waterworks, factories }\end{array}$ \\
\hline 3 May 1949 & $\mathrm{~A}-\mathrm{C}$ & TANARO & $\begin{array}{l}\text { Overflows, Bank erosion, Riverbed Enlargement - } \\
\text { Bank protection }\end{array}$ \\
\hline 10 Nov 1951 & $A-B-E$ & TANARO & Bank erosion - Bank protection \\
\hline 8 Nov 1962 & $\mathrm{~A}-\mathrm{B}$ & TANARO & Overflows, Bank erosion - Bank protection \\
\hline 2 Nov 1968 & $\mathrm{H}-\mathrm{L}-\mathrm{M}$ & $\begin{array}{l}\text { Cherasca, } \\
\text { Misureto }\end{array}$ & $\begin{array}{l}\text { Overflows, Bank erosion - Bank protection, bridges, } \\
\text { railway }\end{array}$ \\
\hline 18 Sep 1973 & $\mathrm{~B}-\mathrm{D}-\mathrm{E}$ & $\begin{array}{l}\text { Riddone, } \\
\text { Canale del Mussotto }\end{array}$ & $\begin{array}{l}\text { Overflows, Floods, Bank erosion - Bank protection, } \\
\text { buildings }\end{array}$ \\
\hline 5-6 Nov 1994 & $\begin{array}{l}A-B-C-D-E-F- \\
G \\
H-K\end{array}$ & $\begin{array}{l}\text { TANARO, Riddone, } \\
\text { Talloria, } \\
\text { Cherasca }\end{array}$ & $\begin{array}{l}\text { Very large inundations, Floods, Bank erosion - Bank } \\
\text { protection, buildings, road network, factories, railway }\end{array}$ \\
\hline
\end{tabular}




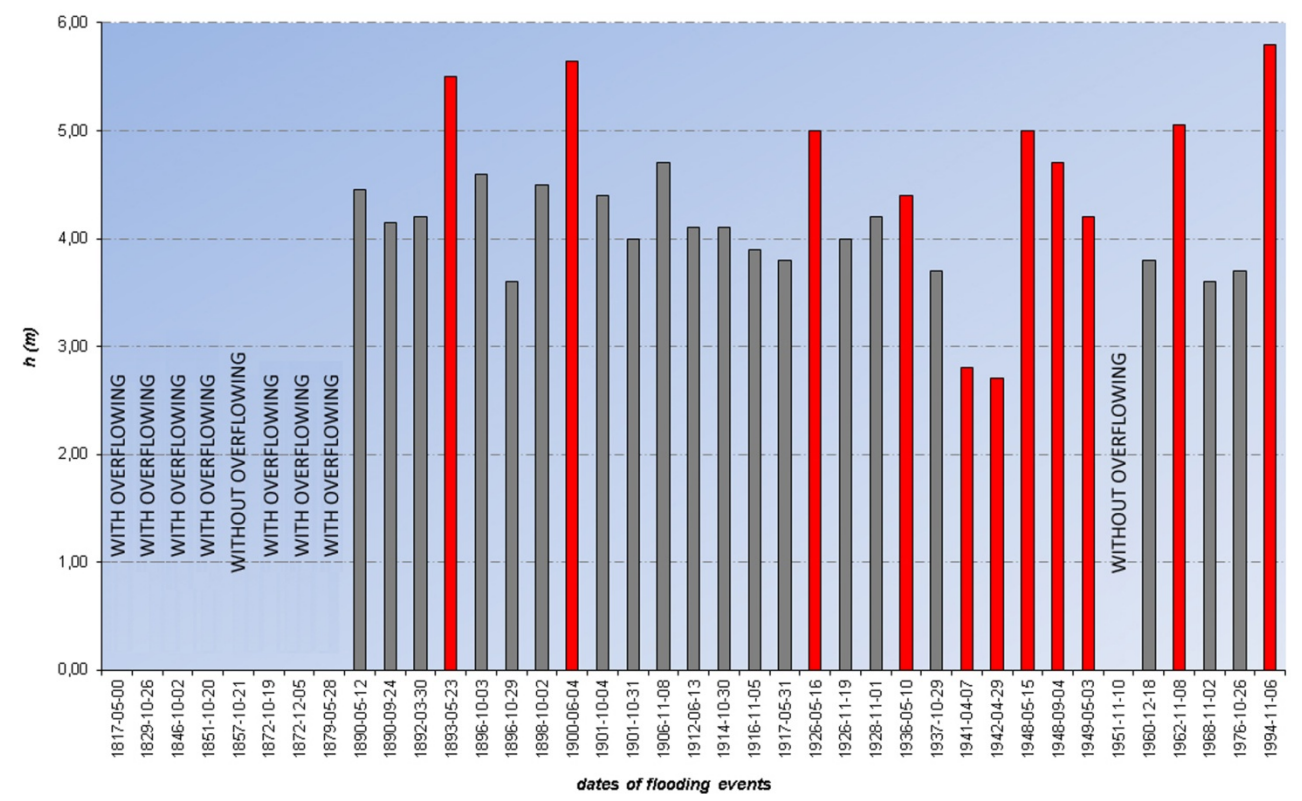

Fig. 7. Tanaro floods during the period 1801-2000 with related hydrometric heights ( $\mathrm{m}$ above gauge datum equivalent to $183.86 \mathrm{~m}$ a.s.1.) measured at the Pollenzo station. Floods causing damage in the Alba area are indicated in red. Floods without hydrometric values are labelled "without overflowing" (no damage) or "with overflowing" (damage).

- For the flood levels measured at the Pollenzo water gauge, a high hydrometric level does not always correspond to reports of damage. In the period between the beginning of measurement (1890) and the Second World War, 20 floods reached heights greater than $3.60 \mathrm{~m}$. However, damage documentation is available for only four floods, which probably indicates that few structures and infrastructures were present in the flooded areas. For the flood of November 1962, little damage was reported, most likely because of the remedial work along the riverbed after the destruction wrought by the four major floods of 1948-1951. In contrast, damage reports exist for the floods of April 1941 and October 1942, which were characterised by modest floodwater heights. It should be noted that the documentation relates mainly to localised flooding and the disruption or destruction of bank protection. Finally, for the November 1968 and September 1973 floods, the reported damage is not attributed to Tanaro floods but to those of the Tanaro's major tributaries.

- During the flood of 4 September 1948, a large number of municipal sectors were affected because of violent erosion and floods of the Cherasca, Talloria and Misureto streams in addition to the extensive Tanaro flooding (see Table 1). On 12 September 1948, a new Tanaro flood struck most of the area that had been affected in the previous week. Despite the new flood's modest height $(2.70 \mathrm{~m})$, the flood is mentioned in the sources because it swept away structures and infrastructure that were already severely damaged. For this reason, and because of the short interval of time between the two floods, the damage caused is not treated separately in the historical documents, and the two floods have been considered a single flood.

- Over the $200 \mathrm{yr}$ investigated, the distribution of the relevant floods is homogeneous ( 9 cases in the 19th century and 12 in the 20th century), although the severity of the floods differed. The tendency of floods to occur in autumn (over $50 \%$ of the floods) is apparent.

- On the basis of the collected information, we can say that among the floods considered, the floods of 1846 , 1879, 1900, 1926, 1948 and 1994 are particularly important because of the extent of the territory affected and the severity of damage. As mentioned above, the area involved can be determined only if the historical documentation provides detailed information on the affected locations (e.g., the names of farms, quarters, and roads). On the basis of such specific information, Table 2 presents the 12 sectors into which the study area has been divided (see Fig. 3), listed in descending order by number of floods.

The historical records show that the Topino-Topinotto farmhouses (A) were inundated at least 15 times between 1801 and 2000. Due to its position on the right bank of a large left bend of the Tanaro River, this site is subject to the natural spreading of floodwaters. In some years $(1846,1872$, $1879,1893,1948$ ), the waters rose 50 to $75 \mathrm{~cm}$. During the 


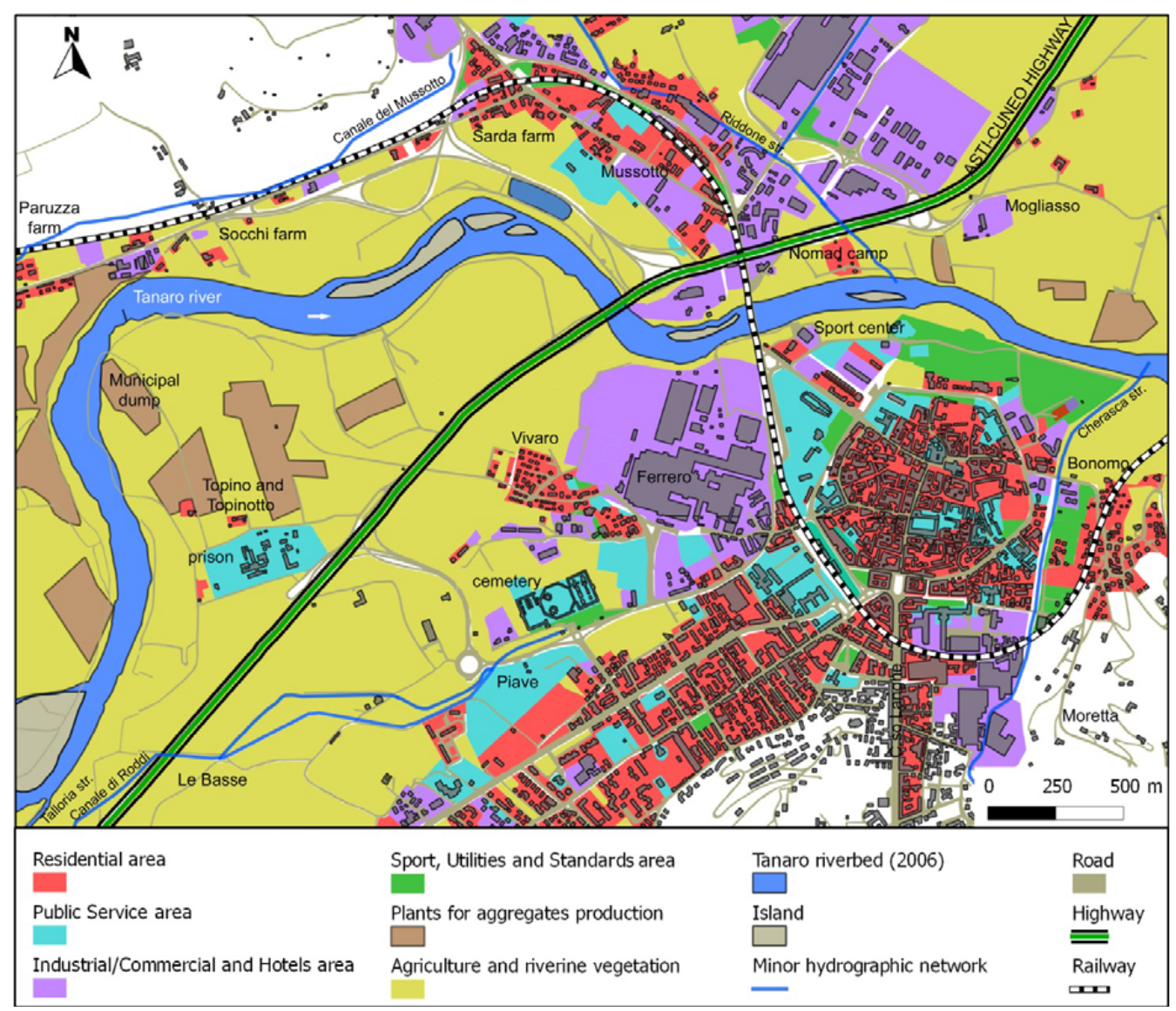

Fig. 8. Urban planning mosaic map of the Alba municipal area. Different colours represent the categories of land use.

Table 2. Areas of the Alba region that have suffered repeated Floods.

\begin{tabular}{lll}
\hline $\begin{array}{l}\text { Areas } \\
\text { (see Fig. 3) }\end{array}$ & Damaged locality & Date of the flood \\
\hline A & Topino-Topinotto zone & $1817-1829-1872-1872-1879-1893-1900-1926-$ \\
& & $1941-1948-1948-1949-1951-1962-1994$ \\
B & Paruzza-Socchi zone & $1846-1851-1879-1893-1900-1942-1948-1948-$ \\
C & Vivaro quarter/Cemetery & $1951-1962-1973-1994$ \\
D & Mussotto SW/Mogliasso/Vaccheria & $1829-1872-1872-1879-1948-1949-1994$ \\
E & Sarda farm/Mussotto NE quarter & $1893-1900-1948-1948-1951-1973-1994$ \\
F & Ferrero/Courthouse & $1879-1893-1941-1948-1948-1994$ \\
G & Le Basse quarter & $1900-1926-1936-1994$ \\
H & Bonomo quarter & $1879-1948-1968-1994$ \\
K & Piave quarter & $1948-1994$ \\
L & Corso Langhe quarter & $1948-1968$ \\
$\mathrm{M}$ & Moretta quarter & $1948-1968$ \\
$\mathrm{~N}$ & Old town & - \\
\hline
\end{tabular}




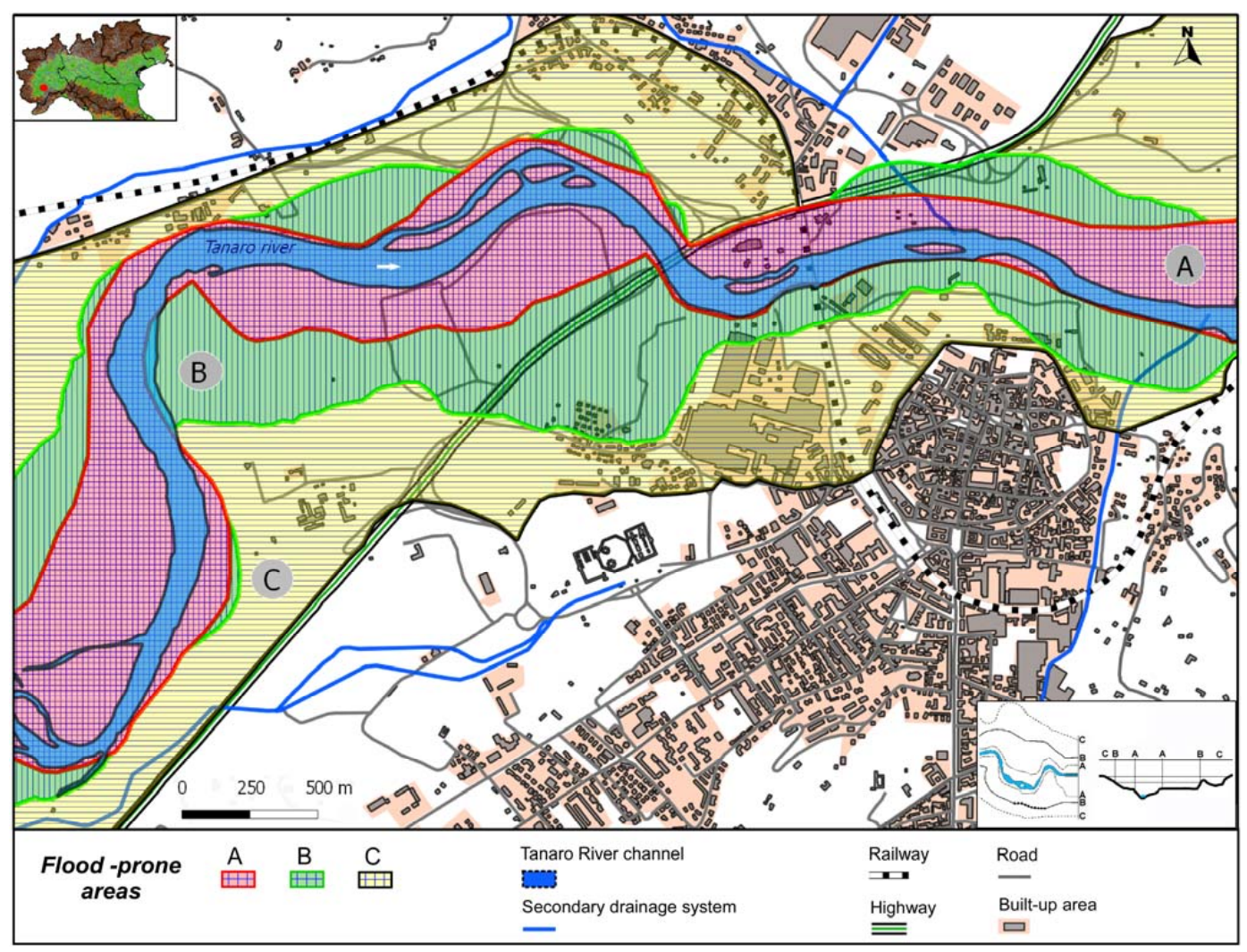

Fig. 9. Alba: subdivision of the Tanaro valley bottom in three different river corridors. $A=$ ordinary floodplain, $B=200-y r$ return period floodplain, $\mathrm{C}=500$-yr return period floodplain. In the lower-right corner the general outline for defining river corridors adopted by the Basin Authorities (Autorità di Bacino del Fiume Po, 1997).

1879 and 1893 floods, farmers had to be rescued from their isolated farmhouses by rowboats.

For many years, this area remained undeveloped because it was known to be particularly prone to flooding. Despite the awareness of the hazard, the municipal dump was established here at the end of the 1970s. Some years later, a large prison was built $700 \mathrm{~m}$ to the south, just behind the main levee. During the November 1994 flood, the Topino-Topinotto zone flooded. The waters deeply eroded the municipal dump, taking tons of refuse with them, and the overflow of water destroyed the 40 to $50 \mathrm{~cm}$ levee surrounding the prison yard.

Another example is the Vivaro quarter (C) on the right bank of the Tanaro River, a low area that has been flooded seven times over the last two centuries. In September 1948, the Talloria flood caused casualties, destroyed houses and roads, and invaded the new Ferrero facility. In the lowest sites, muddy deposits were recorded one meter above the ground. Today, the Vivaro quarter is one of the town's most populous quarters and the site of the Ferrero manufacturing plant.

A final example is the Sarda-Mussotto quarter (D and E). Situated on the left bank of the Tanaro River, the quarter has expanded considerably along the railway and the road to Turin over the last $50 \mathrm{yr}$. Historical records report that at least seven times before the 1994 event, the area was flooded not only by the Tanaro, but also by the Riddone. In 1994, the Riddone flowed partially underground through Mussotto inside a small channel. Now, a large bypass has been built that carries the Riddone around the quarter and reaches the Tanaro across non-urban areas to the north. During the 1994 flood, both the Vivaro and Sarda-Mussotto quarters were inundated. In the lowest sites, the waters reached $3.6 \mathrm{~m}$.

\section{Land-use planning analysis}

Studies of flood-prone areas have been conducted for years without considering land use. However, land-use analysis is an important step in assessing vulnerability, risk and expected damage: land-use regulation is a prerogative granted by the state to local governments. Although case law and planning legislation differ from state to state, general legal principles pertain to all efforts to control land use and development (Waananen et al., 1977). A land-use plan is a key component of a comprehensive plan that includes objectives, policies, and proposals for the type, pattern, and intensity of land use in a planning area. The goal of land-use planning in floodplains is to reduce the expected flood damage and 


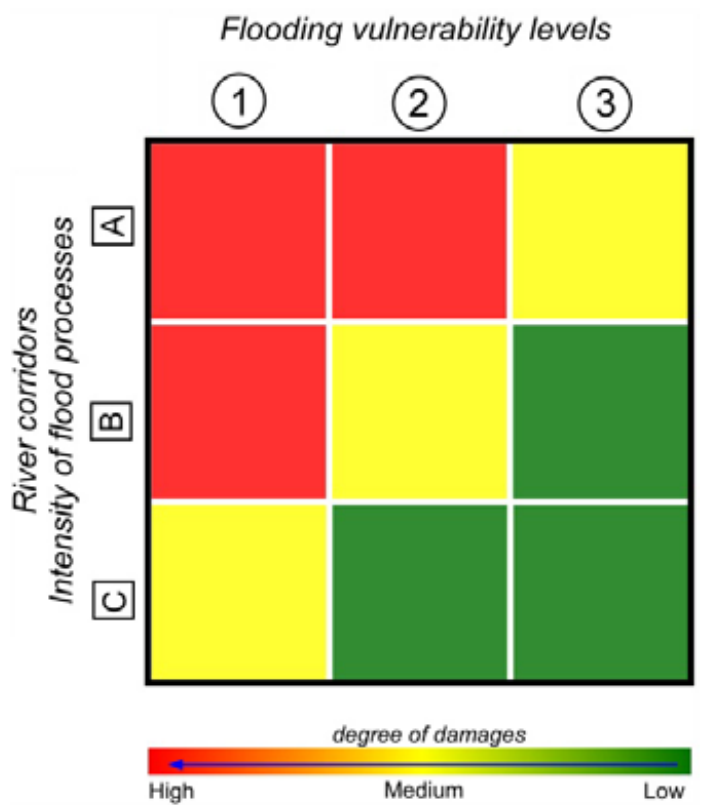

Fig. 10. A risk matrix with three different classes that identify the areas exposed to flooding: green (low degree of damage) to red (high degree of damage).

the risk of development in the floodplain by following less flood-hazardous building practices. To reach this goal, the various land-use options within floodplains must be analysed (Du Plessis and Viljoen, 1999).

Alba's land-use plan was approved just before the 1994 inundation. A new plan was established only in 2011. The new plan takes into account the effects and damage of the 1994 flood. However, the plan mainly considers the remedial works accomplished during these seventeen years.

An analysis of the new land-use plan was performed for the Alba region. The analysis covers both existing built-up areas and future land use while taking into account the planning laws currently in force. Available aerophotogrammetric and cadastral maps were collected to draw an urban zoning map. The territory was subdivided into 6 categories (Fig. 8):

1. Residential areas (red): existing and planned.

2. Public service areas (light blue): areas for municipal buildings, schools, hospitals, barracks, churches, parking areas, storage platforms, purification plants, cemeteries, etc.

3. Industrial, commercial and hotel areas (violet): existing and planned industrial, trade and handicraft activities, commercial buildings, structures and buildings used mainly during the holiday season.

4. Sports, utilities and standards area (green): sport fields and clubs, athletic grounds, public gardens and parks.

5. Aggregate plants and dumps (brown).
6. Agriculture and riverine strip (dark yellow). In these areas, old farms can be renovated and the building volume slightly expanded.

These six categories have been unified into three classes with different flooding vulnerability levels (exposure to flood hazard) according to the following parameters: (a) the presence of a concentration of people over $24 \mathrm{~h}$ or at particular hours of the day; (b) the presence of machinery or private property; (c) the occurrence of social-recreational activities and/or loss from damage to agricultural zones; and (d) the presence of environmentally valuable areas. Residential and public-service areas form LEVEL 1 (highest); industrial, commercial and hotel areas form LEVEL 2; and sports, greenery and agriculture form LEVEL 3 (lowest).

As mentioned in the introduction, the Po River Basin Authority introduced the concept of river corridors: it used hydrodynamic, geomorphological and ecological criteria with the aim to identify three strips of different amplitudes (Fig. 9).

Using a simple risk matrix facilitates a correlation between the hazards of the three river corridors, defined by the Po River Basin Authority, and the exposure level of the land-use classes (Fig. 10).

In the case of Alba, the superimposition of the river corridors on the urban planning mosaic map can highlight the areas with the highest risk levels along the Tanaro valley bottom (Fig. 11).

The aggregate plants and the nomad camp are located in river corridor A (red in Fig. 9), close to the Tanaro riverbed, both on the left bank. The locations are high risk. River corridor B (green in Fig. 9) includes farms and roads as well as the municipal dump, which was partially destroyed during the 1994 inundation, but is still operative (although the dump should be shut down mainly because of the pollution risk). In addition, the Vivaro quarter contains residential buildings, with nearby 2- and 3-story houses and a large group of council houses (bungalows and terraced houses) inhabited by Ferrero employees. These houses were inundated till $1.70 \mathrm{~m}$ in height during the 1994 event.

River corridor $\mathrm{C}$ contains large residential areas, the courthouse, the Ferrero plants, other industrial and commercial areas, hotels, and scattered farms (Topino and Topinotto, zone A in Fig. 6; the Mogliasso-Vaccheria area, zone D in Fig. 6). Farms dot the entire Tanaro floodplain: their grain silos, barns and the new additions built by owners who have not considered the consequences are consistently exposed to risk. However, flood risk is low in the agricultural areas.

Because of building density, river corridor $\mathrm{C}$ has a medium inundation risk, particularly in the Mussotto quarter $(\mathrm{E}$ in Fig. 6). This quarter is characterised by 3 - and 4-story blocks of flats. Many houses have ground-level garages. Some garages are underground, as are most cellars. All ground floors are permanently occupied. 


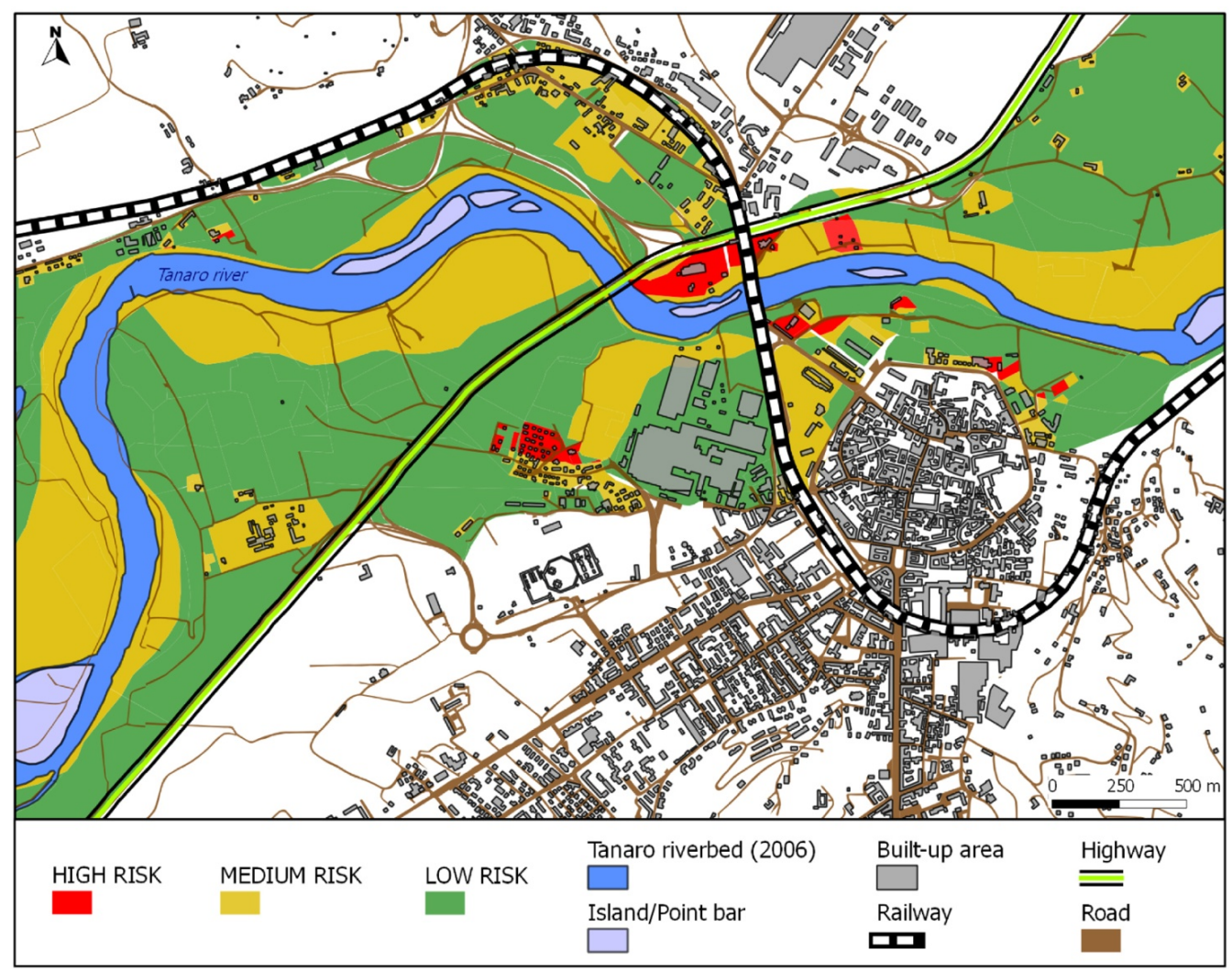

Fig. 11. Final map in which areas with different flood-risk levels have been identified with different colours.

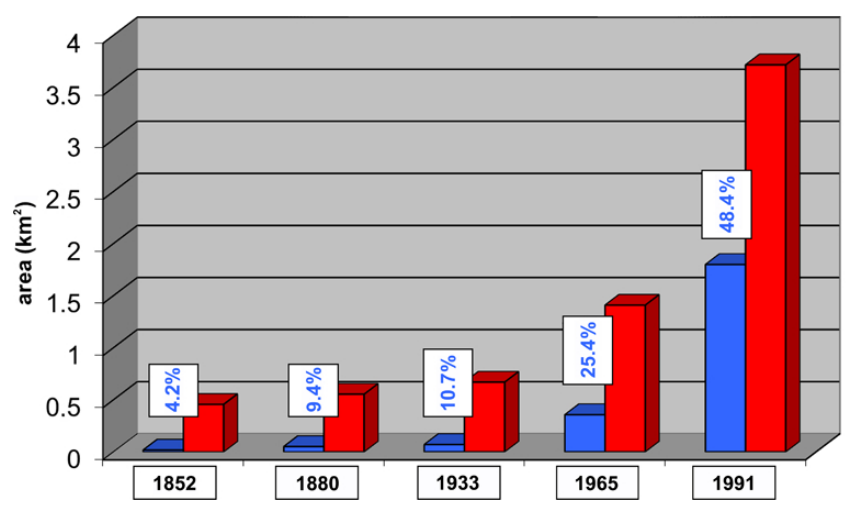

Fig. 12. Urban development of Alba measured from maps of 1852, 1880, 1933, 1965, 1991 (in red), compared with percentage of the urban area would have been flooded in those years by an event similar to that of November 1994 (in blue).

\section{Discussion of the data}

Since 1852, Alba has increased over tenfold in area (from 40 hectares to 475 hectares) by gradually incorporating outlying farms and villages into an urbanised centre for manufacturing and agriculture. Growth rates in urbanisation and population increased quickly after 1950 , when local industry and the commercial development of former farmlands began to expand. The development occurred without taking into account that the newly developed areas were seriously flooded during four floods in 1948-1949. Between 1952 and 1993, only one Tanaro flood (1962) and two tributary floods (1968 and 1973) caused damage. During the roughly $40 \mathrm{yr}$ of undisturbed co-existence with their river, the town's inhabitants developed a feeling of living in safety, which led to development in hazardous areas.

One example is the Topino-Topinotto area (A in Fig. 6), a zone on the right bank subject to the natural expansion of Tanaro floodwaters whose hazardousness had been demonstrated by recurrent floods. This knowledge is confirmed in a report by Cuneo civil engineers (Ministry of Public Works, Office of Civil Engineering, unpublished) in which the critical situation was noted: "Upstream of the city of Alba, at a distance of just more than one kilometre, on the right bank, there is a place that, from an hydraulic point of view, has always been a cause of grave concern for the inhabitants. In this area, called Topino, is found a large bend, where the mass of water acquires a relevant velocity in consequence of a natural shoot of the riverbed, in the stretch immediately preceding the bend...".

For over a century, the local population had avoided building in the most vulnerable area of sector A. In the 1970s, this 
area became the site of a municipal solid-waste landfill. The feasibility study for the municipal dump was accompanied by a geological report that stated, "The area was absolutely out of Tanaro floodings". However, on 5-6 November 1994, the great heap was eroded and swept away by floodwaters, with serious consequences for health and hygiene.

Superficiality and ignorance of the looming hazard in sector A has also allowed the construction of a prison in the immediate vicinity of the levee facing the Topino farm. During the 1994 flood, the floodwaters overtopped and demolished the levee (see Fig. 2) and inundated the land occupied by the prison with $50-60 \mathrm{~cm}$ of water.

In Alba, one factor that has increased the town's vulnerability to flooding is the selection criteria for the development of newly urbanised areas. In a retrospective projection of a 1994-type flood, a comparison of historical with present-day city maps shows that the flooded urbanised areas would have totaled $4.2 \%$ in $1852,9.4 \%$ in $1880,10.7 \%$ in $1933,25.4 \%$ in 1954, and $48.4 \%$ in 1994 (Fig. 12). In the Alba area, an identifiable hazard is the river's tendency to reoccupy the historic riverbed, whether it was originally abandoned naturally or artificially precluded.

During the 1994 flood, for example, on the left bank, in front of the confluence with the Talloria stream (southern sector B), the bank was extensively eroded. The floodwaters first demolished the defense just erected to prevent overflows and then flowed on the ground, digging deep furrows where the river ran before 1954. On the right bank, similar violent processes occurred just downstream from the Topino levee, and water reclaimed the riverbed of 1875 (the area where the municipal dump was established, as mentioned above).

On the left bank, near the Sarda farm, the road embankment intersects with an old Tanaro bend, which was still active in 1933 (see Fig. 6). During the 1994 flood, floodwaters overflowed the embankment, stripping away $100 \mathrm{~m}$ of the upper part and drowning two people who had been driving along the road just as the waves reached it (Fig. 13).

The tendency of the Tanaro to reoccupy the abandoned riverbeds is confirmed by numerous documents relating to the rehabilitation and widening of damaged bank defenses, particularly the deep bank erosions near the Socchi and Sarda farms on the left and the Topino and Topinotto farms on the right.

During the September 1948 flood, for example, the deep erosion of the Socchi bend produced remarkable instabilities: “... The serious situation ... is significantly enhanced for the widening of the bend erosion, which now is only $40 \mathrm{~m}$ from the provincial road Alba-Bra and from the railroad. Besides considerable land, two houses have also been removed" (Consorzio Idraulico di $3^{\text {a }}$ categoria, unpublished).

At four bends, repairs had repeatedly been necessary not only as a result of serious floods but even after ordinary floods to counteract the erosive effect exerted laterally by the river currents to regain the ancient, artificially closed channel.
The negative role played in November 1994 by the road network, particularly the Asti-Cuneo motorway, which was completed in the early 1980s, should also be emphasised. As mentioned in Sect. 3, on both sides of the Tanaro, the structure represented an impediment to the natural spread of floodwaters, locally favouring the accumulation of water volumes that flowed violently once past the obstacle.

This scenario was particularly evident on the Tanaro's right bank approximately one kilometre upstream from the bridge on the highway (see Fig. 4). At the end of the last century, the waters here demolished a levee and inundated the plain of the river (see Fig. 3). The water retained by the road embankment rose more than $5 \mathrm{~m}$ above ground level before passing the lowest point of the barrier (Fig. 14) and inundating the village of Vivaro. Again, tragic consequences occurred. The flood current reached the Ferrero industrial area, already inundated by the waters of the Talloria, and collapsed the plant's eastern perimeter wall, crushing two people.

Although in the final map (Fig. 11) the derivable risk posed by the tributaries has not been considered, it is important to note that areas C, D, E and K in Fig. 2 are crossed by dangerous streams and channels that have caused severe damage in 1994 and in the more distant past. After the 1994 flood, many remedial works were built along the Tanaro and its tributaries. In some locations, the banks have been protected by large boulders to prevent erosion. Specific projects developed for the Talloria, Cherasca and Riddone streams include the removal of vegetation and detritus from the stream beds, an intervention that must be considered unusual. If all works are taken into account, the flood risk has been reduced considerably around Alba.

To limit the violence of fluvial processes and contain the damage such processes can cause, structural and nonstructural interventions must be made in the entire river basin.

\section{Conclusions}

To defend inhabited areas against the effects of the river's natural processes, which often turn catastrophic because they are unforeseen, new fluvial areas must be adequately surveyed before they can be developed.

For most floods, the present banks and wall-protection systems provide sufficient safety for inhabitants because the systems can control the fluvial processes and limit their effects. However, in an extreme event, the speed and violence of the processes overwhelm all defenses. The 1994 Alba flood serves as a classic example of a population caught unprepared.

The analysis has shown the most important natural and man-made reasons why the town was vulnerable to the ravages of the flood. Although the disaster was exceptional, the flood's main natural cause was the Tanaro's tendency to reappropriate its paleochannels, where the floodwaters run with particular violence. Therefore, it is necessary to identify the 


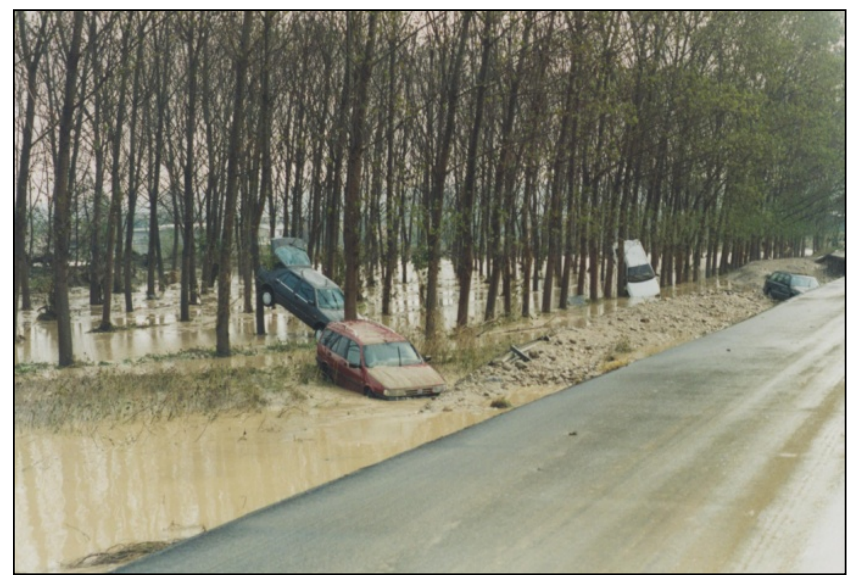

Fig. 13. Tanaro floodwaters swept away cars on the Asti-Cuneo link road, causing two deaths (Y in Fig. 2).

old riverbeds, which are often easily recognisable by morphological evidence on the ground's surface, even where the evidence is partially effaced by mining, farming and widespread poplar plantings. To precisely identify and date the paleochannels, old maps are indispensable.

At a minimum, the following local measures are necessary: (a) the encouragement in a suitable area upstream of the rolling process of the natural subsidence of floodwaters to reduce the flow rates to the bridge and increase the outflow capacity of the riverbed in the urban stretch; (b) the equipping of the embankment of the Asti-Cuneo Highway with fornices to allow the natural outflow of floodwaters and prevent the formation of a reservoir that could overlap the highway and violently release water; (c) the removal from the riverbed and its immediate vicinity every obstacle to the free flow of floodwaters, particularly the disused processing plants (especially the one immediately upstream of the highway bridge), the indigenous tall trees and the thick plantings of poplars; (d) the imposition of severe construction limits in the areas severely damaged in November 1994.

The current condition of the Tanaro floodplain is the product of town-planning choices made in response to the need for space, but without fluvial-hazard evaluation and despite the many relevant documents available.

The summary provided here should be used to review the recent modifications to the town layout. The summary constitutes an indispensable starting point for the identification of land zones with different risk levels that require different planning restrictions.

The current zoning regulations must not only guide decisions about where future urbanisation is most suitable but must also establish criteria for determining the reconstruction of buildings and infrastructure that were damaged by flooding or that played a negative role during floods. The collected information should be managed by a data bank and linked to a GIS so the sites can be located and the stored information

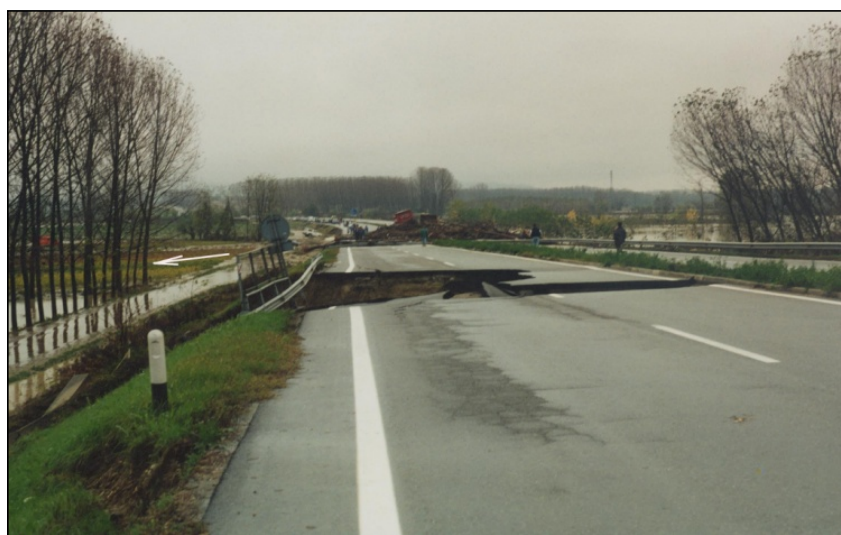

Fig. 14. A large failure caused by the undercutting floodwaters blocked the Asti-Cuneo Highway. In the background, the light subsidence of the highway where the waters overflowed (K in Fig. 2) left a large accumulation of uprooted trees.

retrieved quickly. The data belong in the public domain and should be available to the cadastral register and at the citizens' disposal.

The inhabitants must be warned about impending hazards in the areas where they live. A civil-defense plan must prepare the inhabitants by staging regular flood response drills. The people's safety must be ensured by a tool that can identify areas at different risks, develop an escape plan, and select strategic sites for emergency evacuation and safe shelter. Discouraging development on floodplains may be achieved through billsticking of old photographs and historical data, public-information programs, warning signs, taxassessment practices, financing policies, and public-utility extension policies. Flood insurance requirements and costs may constitute an additional important deterrent.

Acknowledgements. The Authors would like to thank the colleagues Ornella Turitto and Chiara Giorgia Cirio for their help and useful suggestions.

Edited by: D. Castaldini

Reviewed by: two anonymous referees

\section{References}

Arnell, N. W.: Flood insurance and floodplain management, in: "Flood hazard management", edited by: Handmer, J., Geo Books, Norwich, UK, 117-133, 1987.

Aronica, G., Bates, P. D., and Horritt, M. S.: Assessing the uncertainty in distributed model predictions using observed binary pattern information within GLUE, Hydrol. Process., 16, 2001-2016, 2002.

Aureli, F., Mignosa, P., Ziveri, C., and Maranzoni, A.: Fully-2D and quasi-2D modelling of flooding scenarios due to embankment failure, river flow, Taylor and Francis Group, London, ISBN:0415-40815-6, 2006. 
Autorità di Bacino del fiume Po: Piano stralcio delle fasce fluviali, Relazione, 145 pp., 1997 (in Italian).

Baker, V. R., Kockel, R. C., and Patton, P. C.: Flood Geomorphology, Wiley, New York, 503 pp., 1987.

Ballard, J. L., Chave, S., Dupont, N., Masson, E. and Penven, M.-J.: La method hydrogéomorphologique de determination des zones inondables, in: PHYSIO-GÉO, edited by: Martin, C., Géogr. Phys. Environ., ISSN 1958-573X, Collection "Ouvrages", 168 pp., 2011.

Baruffi, F., Rusconi, A., and Surian, N.: Le fasce di pertinenza fluviale nella pianificazione dei bacini idrografici: aspetti metodologici ed applicazioni, Proceedings of INTERPRAEVENT 2004, Riva del Garda (Trento), maggio 2004, 2005 (in Italian).

Bates, P. D. and De Roo, A. P. J.: A simple raster based model for flood inundation simulation, J. Hydrol., 236, 54-77, 2000.

Benito, G. and Hudson, P. F.: Flood hazards: the context of fluvial geomorphology, in: Geomorphological Hazards and Disaster Prevention edited by: Alcantara-Ayala, I. and Goudie, A. S., Cambridge University Press, 111-128, 2010.

Berg, H.: Flood inundation maps-mapping of flood prone areas in Norway, in: "The Extremes of the Extremes: Extraordinary Floods", edited by: Snorasson, A., Finnsdóttir, H. P., and Moss M., IAHS no. 271, 313-316, 2002.

Bhattamishra, R.: Community-Based Risk Management Arrangements: A Review, World Development, 38, 923-932, 2010.

Blanchard-Boehm, R. D., Berry, K. A., and Showalter, P. S.: Should flood insurance be mandatory? Insights in the wake of the 1997 new year's day flood in Reno-Sparks, Nevada, Appl. Geogr., 21, 199-221, 2001.

Brody, S. D., Zahran, S., Highfield, W. E, Himanshu Grover, H., and Vedlitz, A.: Identifying the impact of the built environment on flood damage in Texas, Disasters, 32, 1-18, 2008.

Brych, K., Dittrt, F., and Elias V.: Development of flood boundary maps of urban areas using HEC-RAS software. FRIEND 2002Regional Hydrology: Bridging the Gap between Research and Practice, IAHS Publ. No. 274, 237-242, 2002.

Burrough, P. A.: Principles of geographical information systems for land resource assessment, Clarendon Press, Oxford, UK, 194 pp., 1986.

Caroni, E., Maraga, F., and Turitto, O.: La delimitazione di aree soggette a rischio di inondazione: un approccio multidisciplinare, XXII Convegno di Idraulica e Costruzioni Idrauliche, Cosenza 4-7 ottobre 1990, 9-21, 1990 (in Italian).

Castellarin, A., Domeneghetti, A., and Brath, A.: Identifying robust large-scale flood risk mitigation strategies: a quasi-2d hydraulic model as a tool for the Po river, Phys. Chem. Earth, 36, 299-308, 2011.

Cavallari Murat, A.: Tessuti urbani in Alba. Ist. di Architettura tecnica del Politecnico di Torino. Risultato della ricerca con contributo del CNR: C.T.73.01682.07, Tip. S.A.N. Torino, 160 pp., 1975 (in Italian).

Chen, Y. H. and Simons, D. B.: Hydrology, hydraulics, and geomorphology of the Upper Mississippi River system, Hydrobiologia, 136, 5-19, 1986.

Chouari, W.: Environnement et risques naturels dans le Grand Tunis. Approche cartographique, Thèse de l'Université ParisDiderot, 407 + XXI p., cartes HT, 2009.
Coeur, D. and Lang, M.: Use of documentary sources on past flood events for flood risk management and land planning, Compt. Rendus Geosci., 340, 644-650, 2008.

Consorzio Idraulico di $3^{\text {a }}$ categoria: Commissione Amministrativa (unpubl.) - Programma di lavori per la difesa contro i danni del Fiume Tanaro in conseguenza delle tre alluvioni del maggio, settembre 1948 e del corrente mese, Verbale redatto in data 28 maggio 1949, 1949 (in Italian).

Dawson, C. W. and Wilby, R. L.: A comparison of artificial neural networks used for river forecasting, Hydrol. Earth Syst. Sci., 3, 529-540, doi:10.5194/hess-3-529-1999, 1999.

De Martino, G., Fontana, N., and Giugni, M.: Un modello bidimensionale per la delimitazione di aree inondabili. Atti XXVII Convegno di Idraulica e Costruzioni idrauliche, Genova, 12-15 Settembre 2000, 3, 41-48, 2000 (in Italian).

Destefanis E.: Le difese fluviali saltuarie progettate ed attuate nel Tanaro presso Alba, Annali dei Lavori Pubblici, 1070-1077, 1928 (in Italian).

Diez-Herrero, A., Lain-Huerta, L., and Llorente-Isidro, M.: A Handbook on Flood Hazard Mapping Methodologies, Geol. Surv. Spain, 2, 33-55, 2009.

Du Plessis, L. A. and Viljoen, M. F.: Determining the benefits of flood mitigation measures in the lower Orange River: A GIS application, Water SA, 25, 205-213, 1999.

Dunne, T. and Leopold, L. B.: Water in environmental planning, San Francisco, W. H. Freeman, XXVII, 198 pp., 1978.

Dutto, F.: Proposta metodologica per la definizione della fascia di pertinenza fluviale (FPF) lungo il tratto piemontese del Po. Approccio geomorfologico. Atti del IV Convegno Internazionale di Geoingegneria su "Difesa e valorizzazione del suolo e degli acquiferi”, Torino 10-11 marzo 1994, Associazione Mineraria Subalpina, Torino, 1994 (in Italian).

Esteban, J. F., Izquierdo, B., Lopez, J., Molinari, D., Menoni, S., De Roo, A., Deeming, H., Walker, G., and Eftichidis, G.: Current mitigation practices in the EU, in:"Inside Risk: a strategy for sustainable risk mitigation”, edited by: Menoni, S. and Margottini, C., Springer, 129-186, 2011.

European Community - Directive 2007/60/EC: Official Journal of the European Union, L288/27, 6 November 2007.

Faisal, I. M., Kabir, M. R., and Nishat, A.: Non-structural flood mitigation measures for Dhaka City, Urban Water, 1, 145-153, 1999.

FEMA: The National flood insurance act of 1968, as amended, and the flood disaster protection act of 1973, as amended 42 U.S.C. 4001 et seq. Office of the General Council, USA, 91 pp., 1997.

FEMA: Hazard MH - Multi-hazard Loss Estimation Methodology, Federal Emergency Management Agency, USA, 2003.

Fernández-Lavado, C., Furdada, G., and Marqués, M. A.: Geomorphological method in the elaboration of hazard maps for flash-floods in the municipality of Jucuarán (El Salvador), Nat. Hazards Earth Syst. Sci., 7, 455-465, doi:10.5194/nhess-7-4552007, 2007.

Gardiner, J. L.: River Projects and Conservation. A manual for Holistic Appraisal, J. Wiley and Sons, Chichester, Sussex, 236 pp., 1991.

Giacomelli, A., Mancini, M., and Rosso, R.: Integration of ERS1 PRI imagery and digital terrain models for the assessment of flooded areas: the case of Alessandria (Italy), November 1994, edited by: Luino, F., La prevenzione delle catastrofi idrogeologiche: il contributo della ricerca scientifica, Atti Convegno In- 
ternazionale, Alba (CN), 5-7 Novembre 1996, II, 43-50, 1998.

Gilles, D., Young, N., Schroeder, H., Piotrowski, J., and Chang, Y.: Inundation Mapping Initiatives of the Iowa Flood Center: Statewide Coverage and Detailed Urban Flooding Analysis, Water, 4, 85-106, doi:10.3390/w4010085, 2012.

Glaschen, S., Hausmann, P., Menzinger, I., and Schaad, W.: Floods - an insurable risk?, A market survey Swiss Re, Zurich, 1998.

Govi, M. and Turitto, O.: Problemi di riconoscimento delle fasce di pertinenza fluviale. Atti del IV Convegno Internazionale di Geoingegneria "Difesa e valorizzazione del suolo e degli acquiferi”, Associazione Mineraria Subalpina, Torino 10-11 marzo 1994, 161-172, 1994 (in Italian).

Hardmeyer, K. and Spencer, M. A.: Using Risk-Based Analysis and Geographic Information Systems to Assess Flooding Problems in an Urban Watershed in Rhode Island, Environ. Manage., 39, 563-574, 2007.

Horritt, M. S. and Bates, P. D.: Evaluation of 1D and 2D numerical models for predicting river flood inundation, J. Hydrol. 268, 8799, 2002.

Hui, F., Xu, B., Huang, H., Yu, Q., and Gong, P.: Modelling spatialtemporal change of Poyang Lake using multitemporal Landsat imagery, Int. J. Remote Sens., 29, 5767-5784, 2008.

Jain, S. K., Singh, R. D., Jain, M. K., and Lohani A. K.: Delineation of Flood-Prone Areas Using Remote Sensing Techniques - Water Resour. Manag., 19, 4, 333-347, 2005.

Jonkman, S. N., Bočkarjova, M., Kok, M., and Bernardini, P.: Integrated hydrodynamic and economic modelling of flood damage in the Netherlands, Ecol. Econom., 66, 77-90, 2008.

Kron, W.: Flood insurance: from clients to global financial markets, J. Flood Risk Manage., 2, 68-75, 2009.

Lastra, J., Fernández, E., Díez-Herrero, A., and Marquínez, J.: Flood hazard delineation combining geomorphological and hydrological methods: an example in the Northern Iberian Peninsula, Nat. Hazards, 45, 277-293, 2008.

Lelièvre, M. A., Buffin-Bélanger, T., and Morneau, F.: L'approche hydrogéomorphologique pour la cartographie des zones à risque d'inondation dans les vallées de petites et moyennes tailles: un exemple commenté pour la vallée de la Rivière-au-Renard, in: Comptes rendus de la 4e Conférence canadienne sur les géorisques: des causes à la gestion, edited by: Locat, J., Perret, D., Turmel, D, Demers, D., and Leroueil, S., Presses de l’Université Laval, Québec, 8 pp., 2008.

Leroi, E.: Landslide hazard - Risk maps at different scales: Objectives, tools and development, in: Landslides - Glissements de Terrain, edited by: Senneset, K., 7th. International Symposium on Landslides, Balkema, Trondheim, Norway, 35-51, 1996.

Liu, R. and Liu, N.: Flood area and damage estimation in Zhejiang, China, J. Environ. Manage., 66, 1-8, 2002.

Loáiciga, H. A.: Floods in changing streams, Integrated Water Resources Management, IAHS Publ. No. 272, 325-331, 2001.

Luino, F.: The flood and landslide event of November 4-6, 1994 in Piedmont Region (North-West Italy): causes and related effects in Tanaro Valley, XXII General Assembly of European Geophysical Society, Vienna (Austria), April 21-25, 1997, edited by: Elsevier Science Ltd, 24, 123-129, 1999.

Luino, F.: Flooding vulnerability of a town in the Tanaro Basin: the case of Ceva (Piedmont - Northwest Italy), in: "Paleofloods, Historical Data and Climatic Variability", Proceedings of the PHEFRA International Workshop held in Barcelona, 16-19th Octo- ber, 2002.

Luino, F. and Turitto, O.: L'analisi storica quale elemento d'indagine per l'individuazione delle aree soggette a rischio d'inondazione: il caso di Alba (Italia nordoccidentale), Proceedings of the International Conference: "La prevenzione delle catastrofi idrogeologiche: il contributo della ricerca scientifica", Alba (Italy), November 5-7, 1996, edited by: Luino, F., II, 289300, 1998 (in Italian).

Luino, F., Arattano, M., and Brunamonte, F.: Vulnerability of urban areas to flooding: events in the North-West Italy, November 1994, Proceedings of "Sexto Congreso Nacional y Conferencia Internacional de Geologia Ambiental y Ordenacion del Territorio”, Granada (Spain), 22-25 April 1996, III, 309-327, 1996.

Luino, F., Bassi, M., Fassi, P., Belloni, A., and Padovan, N.: L'importanza delle notizie pregresse quale supporto allo studio geomorfologico per l'individuazione delle aree potenzialmente inondabili ai fini urbanistici: il fondovalle del Torrente Pioverna (Valsassina, Lombardia), Italian Journal of Engineering Geology and Environment, Quaderni di Geologia Applicata - Serie AIGA, 1, 95-109, , 2002a (in Italian).

Luino, F., Belloni, A., and Padovan, N., Bassi, M., Bossuto, P., and Fassi, P.: Historical and geomorphological analysis as a research tool for the identification of flood- prone zones and its role in the revision of town planning: the Oglio basin (Valcamonica Northern Italy), 9th Congress of the International Association for Engineering Geology and the Environment, edited by: Van Rooy, J. L. and Jermy, C. A., Durban (South Africa), 16-20 September 2002, 191-200, 2002b.

Luino, F., Nigrelli, G., Chiarle, M., Biddoccu, M., and Cirio, G. C.: A model for simulating event scenarios and estimating expected economic losses for residential buildings: preliminary results, in: "Flood Risk Assessment and Management Landslides", edited by: Mambretti, S., WIT Press, ISBN: 978-1-84564-646-2, 115128, 2012.

Maraga, F.: Flood-affected areas as related to plain morphology. A case study for flood-prone areas in the Taro River Plain (Northern Italy), VI Meeting of the Working Group "Geomorphology of river and coastal plains", IGU, Sevilla, 1986.

Maraga, F. and Turitto, O.: Diagnosi geomorfologica d'inondabilità in casi di studio sull'idrografia padana, in: LUINO F. (a cura di), "La previsione delle catastrofi idrogeologiche: il contributo della ricerca scientifica". Atti del Convegno Internazionale "Alba 96", Alba (Italia) 5-7 novembre 1996, 313-334, 1998.

Mayer, L. and Nash, D.: Catastrophic Flooding. Binghampton Symposium in Geomorphology, 18, Allen and Unwin, Boston, 410 pp., 1987.

Messner, F. and Meyer, V.: Flood damage, vulnerability and risk perception - Challenges for flood damage research, Flood Risk Management: Hazards, Vulnerability and Mitigation Measures, NATO Science Series: IV: Earth and Environ. Sci., 67, 149-167, 2006.

Munich Re: Flooding and Insurance, Munich Reinsurance Company, 79 pp., 1997.

Musall, M., Oberle, P., and Nestmann F.: Hydraulic Modeling, in: Flood Risk Assessment and Management, edited by: Schumann, A. H., Springer, 9, 187-210, 2011.

Newson, M. D.: Flooding and flood hazard in the United Kingdom. Oxford University Press, 60 pp., 1975. 
Oliveri, E., Noto, L., and Calabro, P.: Metodologie semplificate per la delimitazione di aree a rischio di inondazione. Atti XXVII Convegno di Idraulica e Costruzioni idrauliche, Catania, 9-12 Settembre 1998, 3, 27-39, 1998 (in Italian).

Oya, M.: Geomorphological land classification map of the Neyegawa River basin (Osaka and surrounding area), 1:25,000, indicating areas subject to will be flooding, Publ. Nat Res. Centre Disaster Prevention, Sci. Techn. Agency, Tokyo, 23 pp., 1971.

Pappenberger, F., Frodsham, K., Beven, K., Romanowicz, R., and Matgen, P.: Fuzzy set approach to calibrating distributed flood inundation models using remote sensing observations, Hydrol. Earth Syst. Sci., 11, 739-752, doi:10.5194/hess-11-739-2007, 2007.

Passino, R.: Stato della pianificazione di bacino. In: Ministero LL.PP. Direzione Generale della Difesa del Suolo, 1* Conferenza Nazionale delle Autorita di Bacino, Difesa del suolo e Piani di Bacino, Roma 18 luglio 1995, 77-115, 1996.

Perrone, E.: Carta idrografica d'Italia: Tànaro, No. 2 maps and no. 4 tables. Tip. Cecchini, Roma, 370 pp., 1916 (in Italian).

Prandi, G.: Relazione trasmessa il 4 novembre 1846 agli Illustrissimi Signori Presidente e Consiglieri del Consiglio d'Intendenza generale in Saluzzo, in Italian (unpublished), 1846.

Queensland Government: Disaster loss assessment guidelines, Illycroft Pty Ltd: Queensland, Australia, 111 pp., 2002.

Santos, P. P., Tavares, A. O., and Andrade, A. I. A. S. S.: Comparing historical-hydrogeomorphological reconstitution and hydrological-hydraulic modelling in the estimation of floodprone areas - a case study in Central Portugal, Nat. Hazards Earth Syst. Sci., 11, 1669-1681, doi:10.5194/nhess-11-16692011, 2011.

Sharma, V. K. and Priya, T.: Development strategies for flood prone areas, case study: Patna, India, Disaster Prevent. Manage., 10, 101-109, 2001.

Sinnakaudan, S. K., Ghani, A. A., Ahmad, M. S. S., and Zakaria, N. Z.: Flood risk mapping for Pari River incorporating sediment transport, Environ. Model. Softw., 18, 119-130, 2003.

Smith, D. I. : Flood damage estimation: a review of urban stagedamage curves and loss functions. Water SA, 20, - July, ISSN 0378-4738, 1994.

Sole, A. and D'Angelo, L.: Urban areas flooding processes. Proceedings 3rd DHI Software Conference \& Courses, Helsingor (Denmark), 7-11 June 1999.
Spangle, W. E. and Blair, M. L.: Planning for flood-loss reduction, in: "Flood-prone areas and land-use planning: selected examples from the San Francisco Bay region California", edited by: Waananen, A. O., Limerinos, J. T., and Kockelman, W. J., 3038, 1977.

Tag-Eldeen, M. and Nilsson, L. Y.: Planning processes in disaster prone areas with reference to floods in Tunisia, Disasters, 3, 8994, 1979.

Townsend, P. and Walsh, S. J.: Modeling of floodplain inundation using an integrated GIS with radar and optical remote sensing, Geomorphology, 21, 295-312, 1998.

Tropeano, D. and Turconi, L.: Using Historical Documents for Landslide, Debris Flow and Stream Flood Prevention. Applications in Northern Italy, Nat. Hazards, 31, 663-679, 2004.

Tucci, C. E. M. and Villanueva, A. O. N.: Flood control measures in União da Vitoria and Porto União structural vs. non-structural measures, Urban Water 1, 177-482, 1999.

United Nations: Guidelines for Reducing Flood Losses - United Nations, ISDR, available at: http://www.unisdr.org/eng/library/ lib-index.htm (last access: March 2012), 2006.

Van der Sande, C.: River flood damage assessment using IKONOS imagery, E.C. Joint Research Centre \& S.A.I., Ispra, Italy, 77 pp., 2001.

Van Westen, C. J., Van Asch, T. W. J., and Soeters, R.: Landslide hazard and risk zonation: why is it still so difficult?, Bull. Eng. Geol. Environ., 65, 67-184, doi:10.1007/s10064-005-0023$0,2006$.

Van Westen, C. J., Castellanos, E., and Kuriakose, S. L.: Spatial data for landslide susceptibility, hazard, and vulnerability assessment: An overview, Eng. Geol., 102, 112-131, doi:10.1016/j.enggeo.2008.03.010, 2008.

Waananen, A. O., Limerinos, J. T., Kockelman, W. J., Spangle, W. E., and Blair, M. L.: Flood-prone areas and land-use planning: selected examples from the San Francisco Bay region, California. US, Geological Survey Professional Paper, 942, 75 pp., 1977.

Wolman, M. G.: Evaluating alternative techniques of floodplain mapping, Water Resour. Res., 7, 1383-1392, 1971. 